\title{
THE ASSESSMENT OF JOINT PURCHASING: CAN TOO MUCH 'BUYING POWER' EVER BE A PROBLEM
}

\author{
Paul Anderson* \\ Genesis Analytics (Pty) Ltd \\ paula@genesis-analytics.com \\ Fatima Fiandeiro\# \\ Genesis Analytics (Pty) Ltd \\ fatimaf@genesis-analytics.com \\ Keshav Choudhary+ \\ Genesis Analytics (Pty) Ltd \\ keshav.choudhary@hotmail.com
}

July 2011

\begin{abstract}
The creation of 'buying power' through joint purchasing agreements is often seen as positive, with direct benefits for consumers in the form of lower prices. Even where joint purchasing agreements lead to the creation of a monopsonist, economic theory suggests that the welfare effects of monopsony power depend greatly on the market context, with some economists proposing that the probability of harm in cases involving monopsony power is considerably lower than in cases of a monopoly.

Despite this view, section 4(1)(b) of the South African Competition Act classifies the 'fixing of a purchase or selling price or any other trading condition' by competitors as a per se prohibition. This implies that from a legal perspective purchasing agreements may be afforded the same draconian treatment as selling cartels. This paper considers whether this potentially punitive treatment of joint buying arrangements under section $4(\mathrm{l})(\mathrm{b})$ is warranted and indeed whether the equivalent treatment of joint buying and selling agreements under this section of the Act is appropriate.
\end{abstract}

\section{Keywords}

Joint purchasing; monopsony; buying power; buyer cartel; Section 4(1)(b); South African Competition Act

\footnotetext{
* Mr Paul Anderson is an economist at Genesis Analytics, Hyde Park, Johannesburg, South Africa.

\# Ms Fatima Fiandeiro is an economist at Genesis Analytics, Hyde Park, Johannesburg, South Africa.

+Mr Keshav Choudhary is an economist at Genesis Analytics, Hyde Park, Johannesburg, South Africa
} 


\section{INTRODUCTION}

The creation of buying power through joint purchasing agreements is often positive, with direct benefits for consumers in the form of lower prices. Even where joint purchasing agreements lead to the creation of a monopsonist (i.e. a single buyer), economic theory suggests that the welfare effects depend to a large degree on the market context, with some economists proposing that the probability of harm in cases involving monopsony power is considerably lower than in cases of a monopoly. Jacobson and Dorman (1992:165) go as far as to claim that "... true monopsony power is rare and that net adverse effects on price and output from monopsony are even rarer".

Despite this view, section 4(1)(b) of the South African Competition Act (Act) classifies the "... fixing of a purchase or selling price or any other trading condition ..." [emphasis added] by competitors as a per se prohibition. This implies that many joint purchasing arrangements which often by their nature require a setting of a common purchase price - may be afforded the same draconian treatment as hard-core selling cartels in the Competition Act. That is, competitors who form buying groups that jointly set a purchase price could fall within section $4(1)$ (b) of the Act and this practice could not be justified by demonstrating an insignificant impact on competition, or by invoking the defences provided for in section 4(1) (a) of the Act.

While there may be some (arguably limited) scope to suggest that certain joint selling arrangements which require the fixing of a common selling price may ultimately be efficiency enhancing and pro-competitive, this would appear to hold abundantly more so for joint purchasing agreements. This would seem to be particularly true within a South African context (as discussed later in this paper). Thus, there is a real danger that South African firms, often small-to-medium-sized firms, steer away from efficiency enhancing and pro-competitive joint buying arrangements out of a potential risk of technically falling foul of the per se prohibition contained in section 4(1)(b) of the Act.

This paper considers whether this potentially punitive treatment of joint buying arrangements under section $4(\mathrm{l})(\mathrm{b})$ is warranted and indeed whether the equivalent treatment of joint buying and selling agreements under this section of the Act is appropriate. Our analysis takes the following approach: Firstly, the potential theories of harm at which section 4(1)(b) would seem to be aimed are considered. Then, the underlying economic theory and intuition behind a monopsony outcome is explored. The conditions necessary for competitive harm to be inflicted are then examined within a South African context. Finally, we consider the implications for the treatment of joint purchasing before concluding.

\section{THEORIES OF HARM RELATING TO JOINT BUYING TARGETED UNDER SECTION 4}

There would seem to be two main potential theories of harm associated with joint-buying conduct which section 4 of the Act would seek to address, namely: downstream co-ordination among the buyers and abuse of monopsony power by restricting purchases. These are considered below.

With downstream coordination, there is the possibility that buying groups are used as an instrument to facilitate collusion at the downstream level. Co-ordination in the purchasing decisions of buyers regarding quantities purchased, for example, could affect the quantity 
produced at the downstream level. Buying groups could potentially be used as a tool to enforce collusion downstream through the control of upstream input purchases. Alternatively, even if there is no co-ordination on quantities purchased, the standardisation of input costs may also facilitate collusion, as variation in costs is one of the factors that contribute towards the instability of collusive arrangements.

Harmful monopsony behaviour refers to a situation where a powerful buyer essentially has the ability to restrict its own purchases of product and thereby - by virtue of its powerful market position - depress the price of the product in question below the competitive level. The harm from this conduct is essentially exploitative in nature and is equivalent (from a welfare perspective) to a monopoly exploiting its market power on the selling side. The mechanics behind this behaviour and its welfare implications are discussed in detail in the next section.

\subsection{Theory of harm under section $4(1)(b)$}

It is generally accepted that the main concern which motivates a per se prohibition of coordinated horizontal behaviour is the exploitative effect of prices being raised above the competitive level in the case of selling-side co-ordination, and prices being depressed below the competitive level in the case of buying-side coordination.

While recognising the potential for buying groups to facilitate tacit collusion downstream it cannot be assumed that buying groups automatically result in downstream collusion. Rather, a careful consideration of the facts of the case is required. For instance, it may be that the downstream market itself is not conducive to collusion, or those participants to the purchasing agreement account for a small combined share of the downstream market where they compete. Furthermore, the sharing of final selling prices and quantities is seen as more problematic as it eliminates uncertainty regarding a competitor's conduct, while knowing the input price of a competitor may be of limited value to a competitor, particularly if the input comprises only a small portion of final costs. Therefore a minimum requirement for joint buying to impose this form of harm would be for the parties concerned to

(i) also be competitors downstream; and

(ii) for the input in question to be significant in the overall build-up of the downstream product (around which the downstream coordination could occur).

Therefore given this indirect link to downstream harm, which cannot automatically be assumed, it would seem convoluted and incorrect to consider all joint buying as per se prohibited (under section $4(1)(b)$ ) on the basis that it may facilitate downstream collusion under certain conditions. Rather, if this were the primary concern with joint buying arrangements it would appear more appropriate for them to be considered under the rule-of-reason approach of section $4(1)(a)$. Indeed, in the $E U$ and US this indirect theory of harm would generally not justify a joint purchasing agreement being considered as per se illegal.

As such the primary mechanism of harm stemming from joint buying activities, which section $4(1)$ (b) would seem to be aimed at curtailing, would appear to be the abuse of monopsony power and the associated depression of prices below the competitive level. The remainder of this paper therefore focuses on this theory of harm and assesses whether it is appropriate, from an economic point of view, to treat the joint purchasing as a per se contravention. The analysis of this theory of harm also provides insight into whether the equivalent treatment of joint purchasing and selling agreements has merit. 


\section{THE ECONOMICS OF BUYER POWER}

A useful definition of buyer power is "the ability of a buyer to reduce the price profitably below a supplier's normal selling price, or more generally the ability to obtain terms of trade more favourable than a supplier's normal terms" (Chen, 2007:19). Buyer power can arise when there is a single buyer of an input (a monopsonist), or where there are a few large buyers (an oligopsony). It can also arise from joint purchasing agreements which form the basis for buyer groups and which enable smaller firms to act collectively to mimic the outcomes of a monopsonist. If a buyer group is formed for the purpose of gaining market power over the group's suppliers, the effects of such buyer power can be analysed in more or less the same as in the case of a single buyer (Chen, 2007:26).

A distinction is often made in the literature between two types of buyer power: monopsony power and bargaining power (Chen, 2007:20; 0ECD, 2008:9; 0FT, 2007:4-5). For the purposes of this paper, we define monopsony power as the ability to restrict the market price of an input to below the competitive level by withholding purchases (Chen, 2007:20), while bargaining power refers to the bargaining strength that a buyer has with respect to its suppliers (OECD, 2008:37). This section describes the standard economic theory behind the exercise of monopsony power and discusses the welfare implications for sellers, end consumers and total social welfare. The model is also extended to consider the welfare effects of monopsony power where there is imperfect competition upstream.

\subsection{The basic model of monopsony}

The standard theory of monopsony discussed in this section draws from the analysis provided in standard microeconomics texts (Varian, 1996:449; Carlton \& Perloff, 2005:107; Griffiths \& Wall, 2000:403; OFT, 1998:11). Since it is difficult to sustain monopsonies by end users of a commodity, this type of behaviour is generally exhibited in input markets where a firm may have monopsony power in the purchase of inputs that it uses to manufacture and sell final products downstream. This is the model used in this case and is the standard model used in the literature.

The basic model is discussed first, in which the presence of a monopsonist is the only market imperfection. More specifically, the basic model makes the following assumptions:

(i) It is assumed that in the upstream market, perfectly competitive firms (the sellers) produce a perfectly homogeneous commodity $x$ which is used as the only input in the production process of a firm (the monopsonist) that sells the final product to end consumers downstream;

(ii) the buyer is a monopsonist in the upstream market but sells the final product in a perfectly competitive market downstream; and

(iii) it is assumed that the marginal costs for the input suppliers are rising over the relevant ranges of output. Since the short-run supply curve for each competitive seller is exactly the portion of the marginal cost curve lying above the average cost curve (Varian, 1996:370), it follows that the supply curve for a seller upstream (and the whole industry, by aggregation) is upward sloping in the short run.

Since a monopsony is a sole buyer, any additional purchases of a product will force up the price for al/ units of that product. In other words, the true marginal cost to the buyer of purchasing an extra unit will be both the cost of the last unit plus the additional cost because all units now cost more. This results in a true marginal cost curve (also called the marginal factor cost (MFC) 
curve) lying above the producer's supply curve. To maximise profits, the monopsonist purchases up to the point where this inflated marginal cost of purchasing an additional unit (or MFC) equals the marginal value to it of that unit (classically represented by the derived demand curve). This is illustrated in FIGURE $\mathbf{1}$ (also see APPENDIX $\mathbf{1}$ for a mathematical representation of the profit-maximising condition).

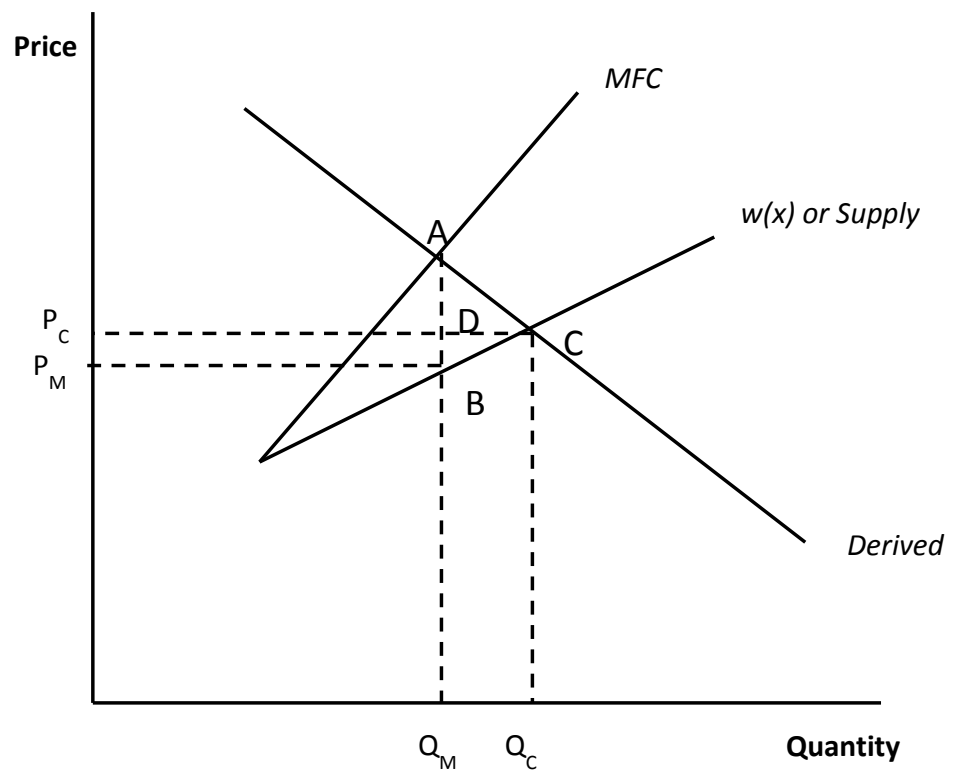

\section{FIGURE 1: Representation of Welfare Effects under a Monopsony Market Structure}

\section{Source: $\quad A B A(2008: 396)$}

If the monopsonist lacked buying power (in other words, if it were a competitive buyer), it would equate $w(x)$ (which represents the supply curve of the sellers) with the derived demand and purchase $Q_{C}$ at price $P_{C}$. By contrast, the monopsonist equates his actual marginal cost or MFC (which lies above $w(x)$ ) with the derived demand and purchases $Q_{M}$ at price $P_{M}$. Thus a pure monopsony effect involves restricting output and lowering the price paid to the upstream supplier as compared to the competitive outcome. This also creates a deadweight loss to society given by the shaded triangle $A B C$. The rationale for this loss is that if output were expanded beyond $Q_{M}$ up to $Q_{C}$, it would enhance efficiency for society, since the price that the buyer would be willing to pay would still exceed the price at which the suppliers would be willing to supply.

The exercise of monopsony power illustrates various implications for welfare. Sellers are impacted by the monopsonist making use of its buying power in order to restrict output and thus lower the price paid for commodity $x$ relative to the competitive outcome. Note that even though the monopsonist pays price $P_{M}$ to the sellers, which is lower than the competitive price (i.e. the price that would be paid out if there was no monopsony power), this price is determined from the supply curve of the sellers so that they are willing to sell quantity $Q_{M}$ at price $P_{M}$. Consequently, the producer's surplus (in this case the seller's) unambiguously declines by the area $P_{C} D C B P_{M}$. Out of this, the area $P_{C} D B P_{M}$ represents a wealth transfer from the sellers to the monopsonist buyer (Alexander, 2007:1615). The rest of the area becomes part of the 
deadweight loss to society.

There is an unambiguous decline in total welfare. Monopsonistic behaviour creates a deadweight loss to society (represented by the area $A B C$ ) which results in an overall inefficiency that would be absent in a competitive outcome.

The welfare impact on end consumers in the case where there is competition downstream is the subject of some debate. According to OECD (2008:29), the impact on end consumers is negative even with the presence of perfect competition downstream. This is because even with perfect competition downstream, the monopsonist restricts the purchase of output (owing to its higher marginal cost or MFC). As a result, total output reduces downstream and prices to end consumers increase. This is because by restricting input purchase, the monopsonist benefits via lower average costs that increases its profits, but effectively behaves as if its marginal costs were higher, due to which its output downstream is lower and prices to end consumers actually higher (ABA, 2008:397). If however, the supply by the competitors in the downstream market is perfectly elastic, it has been argued that there is no impact on end consumers since other firms in the market are expected to make up for the shortfall in output resulting in no change in prices or quantity (Jacobson \& Dorman, 1992:161; 0ECD, 2008:30; Salop, 2005:673; Alexander, 2007:1617). Areeda and Hovenkamp (2003:91) summarise this case by saying, "[i]n sum, in this case there is literally no injury to 'consumers' who are the main concern of antitrust laws, but the injury is to producers who are forced to accept lower profits and to make inefficient substitutions to other products." Noll (2005:599), however, has suggested that even in this situation, the impact on end consumers is negative. His argument hinges on varying productivity of the inputs (in the preceding analysis, inputs have been assumed to be completely homogeneous). According to Noll (2005:599), if monopsonistic behaviour results in lower purchases of productive inputs and if the corresponding shortfall in output is made up by other downstream firms employing less productive inputs, then more inputs will now be required to produce the final good as compared to a competitive outcome. As a result the real price of the downstream good would increase, making consumers worse off overall. The preceding arguments thus suggest that even though the monopsonist pays lower prices upstream, the price impact on end consumers is either negative or neutral.

The basic model assumes that the monopsonist possesses buying power in the input market and is one of many competitive price-takers downstream in the output market. However, harm is exacerbated if the monopsonist is also a monopoly seller of its own product. This is because profit maximisation by such a firm would result in a further reduction of the price and quantity in the input market (by affecting the marginal revenue downstream and thus the marginal value from input purchases). This reduction carries through to the output market of the monopsonist and therefore raises prices to the final consumer while increasing the margin of the monopsonist.

\subsection{Bilateral monopoly}

The basic model can be extended to consider the case when market power is present on the selling side of the input market. A market structure where a monopolist sells its output to a monopsonist is called a bilateral monopoly. The analysis here follows Griffiths and Wall (2000:403-404). As noted in the text, the relevant demand curve of the monopsonist considered is the MRP curve, since the downstream market is assumed to have seller power. This extension considers the downstream market to be competitive, so the relevant curve is the Value of Marginal Product (VMP) curve instead (Griffiths \& Wall, 2000:404). For simplicity's sake, it is 
assumed that the monopsonist operates as a perfectly competitive firm downstream. As noted in the appendix, the VMP curve is the derived demand curve of the monopsonist. However, this is also the Average Revenue curve of the monopolist, since it tells the monopolist the price it can expect to receive for different quantities of input sold. Furthermore, since the monopolist has selling power, it knows that it faces a downward sloping demand curve and that it must reduce the price of the commodity $x$ if it wants to sell more. Therefore, as is standard in the case of a monopoly, the marginal revenue curve for the seller will lie below its average revenue curve and the monopolist would like to sell that quantity where its marginal revenue equals marginal cost.

However, the presence of the monopsonist on the other side of the input market implies that this is not necessarily the case. The exact outcome is ambiguous and depends on the relative bargaining strengths of the two parties. It is only possible to determine the boundaries within which the solution must lie (Griffiths \& Wall, 2000:310).

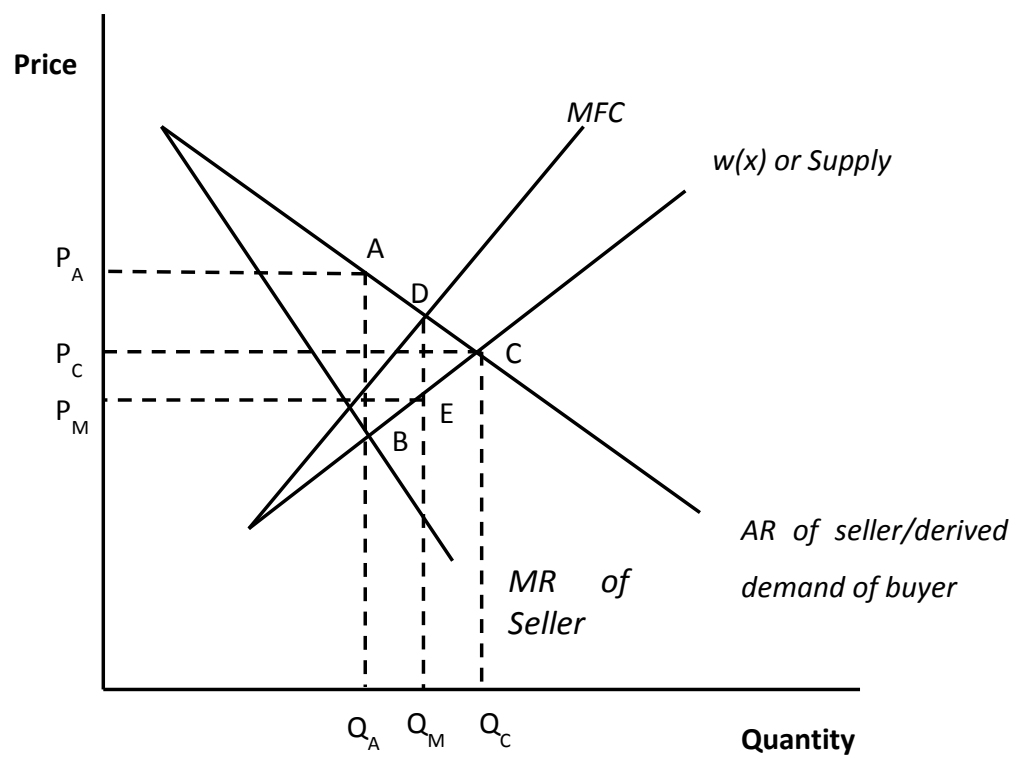

\section{FIGURE 2: Representation of Welfare Effects under a Bilateral Monopoly Market Structure}

Source: $A B A(2008: 397)$

As shown in the figure above, the competitive outcome results at price $P_{C}$ and quantity $Q_{C}$. This is where the marginal cost of production equals the demand for the input. If the monopsonist possesses all the bargaining power, it effectively makes the monopolist act as a competitive supplier. As a result, the $w(x)$ curve becomes the supply curve and the basic monopsony outcome results in price $P_{M}$ and quantity $Q_{M}$. If, however, the monopolist has all the bargaining power, it equates its marginal cost with its marginal revenue and the outcome is price $P_{A}$ and quantity $Q_{A}$. Thus, depending on the relative bargaining strengths, the actual price of the input could be either above or below the competitive level.

Since the exact outcome in the case of a bilateral monopoly is uncertain, so is the overall welfare impact. It is possible that the exercise of monopsony power in such a situation could have a beneficial impact on total welfare (OECD, 2008:36). As an example, consider the situation where the buyer could exert no monopsony power. In this case, the seller would possess 
monopoly power. It would decide to sell the quantity of input where its marginal revenue equalled marginal cost and would sell quantity $Q_{A}$ and price $P_{A}$. In this situation, there would be a deadweight loss to society given by the area $A B C$. If, however, the buyer were able to start exerting monopsony power, it would do no worse than the monopoly outcome (since it could simply accept the monopolist's offer), but, depending on the relative bargaining strength, it could force the monopolist to increase the quantity sold towards $Q_{M}$ and bring the price down towards the competitive level, thereby reducing the distortions in the market. This argument suggests that monopsony power might have a beneficial impact on society, especially when it develops as a response to monopoly power in the input market (OECD, 2008:36). However, it should be emphasised that even in the extreme case where the monopsonist has all the bargaining power, there is still a welfare loss to society given by the area DEC.

The analysis above suggests that since the price and quantity of purchase of inputs in the upstream market is uncertain, the impact on end consumers is also uncertain. Depending on whether the bargaining power of the involved parties results in an increase or decrease in inputs purchased (from the competitive level), final output and thus prices paid by end consumers are accordingly uncertain (0ECD, 2008:36). If the exercise of monopsony power acts as a countervailing force to market power on the selling side, it would result in an increased purchase of inputs, greater output and lower prices to end consumers (OECD, 2008:36).

\subsection{Efficiencies}

In addition to the benefits that arise from reducing upstream market power, efficiencies that flow from buyer power may off-set, at least to some extent, the deadweight loss associated with monopsony power. Off-setting efficiencies are not explicitly modelled in the textbook monopsony representation, yet the notion that joint purchasing arrangements have the potential to yield pro-competitive and efficient outcomes is uncontroversial (OFT, 2007:8-12; Chen, 2007:27; Areeda \& Hovenkamp, 2003:96). Buyer power can result in lower prices by reducing transaction costs. This could occur in situations where it is cheaper to deal with a single buyer instead of a number of individual buyers. For example, there may be economies of scale to a supplier's distribution system such that the average cost of processing a large purchase order is lower than that of a small order (Chen, 2007:28). When such a situation arises, a supplier may offer volume discounts to encourage large purchase orders and smaller buyers may be able to receive the volume discounts by pooling their purchases. The extent to which lower prices are passed through to final consumers depends on the degree of competition downstream. The more downstream competition there is, the higher the degree of pass-through expected, and the greater the benefit to consumers (0ECD, 2008:10; 0FT, 2007:59-60).

\subsection{Conclusion on welfare effects}

Intuitively it may appear that any practice that leads to a lower price is beneficial and should therefore be encouraged; the standard monopsony theory reveals that monopsony power results in a deadweight loss to society which is analogous to the deadweight loss associated with a monopoly. Furthermore, lower prices are not necessarily passed on to final consumers, even when competition is present downstream. However, the economics literature also reveals that the monopsony outcome depends on a number of factors, which are explored further in the subsequent section. 


\section{CONDITIONS NECESSARY FOR HARM}

The welfare effects of buyer power are dependent on the market context, with some arguing that "competition authorities are more likely to be confronted with situations where the monopsony assumptions fail" (OFT, 2007:54). This is in contrast to selling power, where collaboration among sellers on price is almost always anti-competitive (unless it involves substantial efficiency benefits which require the fixing of a selling price). A perusal of the economic literature reveals that the monopsony result hinges on a few key factors, namely:

(i) the degree of seller power upstream;

(ii) the shape of the supply curve; and

(iii) the presence of off-setting efficiencies. These factors are discussed in turn in this section.

\subsection{Seller power}

As illustrated by the bilateral monopoly scenario, a pre-condition for harm is that the seller market is competitive. It is recognised in the $\mathrm{EU}$ case law that where there is market power in the upstream selling market, countervailing buyer power can be used to moderate price increases (This was recognised in Grovvareforeninger v. Dansk Landbrugs Grovvareselskab, as noted in OECD (2008:257)). The criticism of a monopsony may thus be less valid when market imperfections exist on both the purchasing and supply side. This point is particularly relevant to the South African context, as it is generally acknowledged that the South African economy is highly concentrated. Studies such as Fedderke and Szalontai (2005) have compiled concentration measures for 24 different manufacturing industries in South Africa from 19721996. The general consensus is that these industries have historically been highly concentrated and the trend over the years has been an increase in concentration rather than a decrease. Moreover, it has been argued that concentration levels are generally high upstream, in intermediate goods industries owing to large economies of scale, high transport costs and a lack of regional competition in these industries (Roberts \& Zalk, 2004:1).

The view that many upstream manufacturing industries in South Africa are concentrated is also reflected in TABL $\mathbf{1}$ which shows concentration measures for a few industries that are likely to be considered upstream industries. CR4 and CR10 are commonly used concentration measures. These indicate the market share owned by the largest firms in an industry and are obtained by simply summing up the market shares of the 4 or 10 largest firms in an industry respectively. CR4 and CR10 are expressed as a percentage - a low percentage indicates a high level of competition, since this means that the largest firms themselves have low market share, while a high percentage indicates an oligopoly or monopoly. In a number of the industries listed, the ratios suggest that they are concentrated, with the relative share of the four largest firms above $60 \%$ and the share of the ten largest firms above $70 \%$. Many of these industries, such as basic iron and steel, chemicals and rubber products, are likely to be significant inputs in a range of downstream manufacturing industries. See also Malikane and Roberts (2001) and Roberts (2004), who discuss concentration in the South African plastics and steel industries respectively, which produce products that are used as inputs in a range of downstream industries. 
TABLE 1: Some upstream concentration ratios in the manufacturing industry according to output: 2005

\begin{tabular}{lcc}
\hline Type of manufacturing & $\begin{array}{c}\text { Relative } \\
\text { contribution of } \\
\text { four largest } \\
\text { firms (CR4)(\%) }\end{array}$ & $\begin{array}{c}\text { Relative } \\
\text { contribution of } \\
\text { ten largest } \\
\text { firms (CR10) } \\
(\%)\end{array}$ \\
\hline Coke oven products & 63.47 & 96.93 \\
Basic chemicals & 65.89 & 75.57 \\
Rubber products & 66.65 & 76.35 \\
Basic iron and steel & 72.13 & 84.64 \\
Basic non-ferrous and precious metals & 59.35 & 74.33 \\
Insulated wire and cable & 69.57 & 88.22 \\
\hline
\end{tabular}

Source: Statistics South Africa, Report No. 30-02-02 (2005), Table 19, p. 145-150.

TABLE 2 reports concentration ratios for certain industries that are considered to be downstream. The concentration ratios suggest that that the downstream industries are generally less concentrated than the industries that are considered to be upstream, although there are also instances of downstream industries that are highly concentrated, such as motor vehicles and paper products.

\section{TABLE 2: Some downstream concentration ratios in the manufacturing industry according to} output: 2005

\begin{tabular}{lcc}
\hline Type of manufacturing & $\begin{array}{c}\text { Relative } \\
\text { contribution of } \\
\text { four largest } \\
\text { firms (CR4) (\%) }\end{array}$ & $\begin{array}{c}\text { Relative } \\
\text { contribution of } \\
\text { ten largest } \\
\text { firms (CR10) } \\
(\%)\end{array}$ \\
\hline Wearing apparel, except fur apparel & 31.91 & 41.53 \\
Footwear & 29.94 & 48.5 \\
Plastic products & 15.96 & 24.76 \\
Paper and paper products & 66.86 & 77.77 \\
Furniture & 26.54 & 33.17 \\
General purpose machinery & 7.78 & 15.53 \\
Special purpose machinery & 34.52 & 41.88 \\
Other fabricated metal products and metalwork service & 16.9 & 21.89 \\
activities & 75.09 & 95.21 \\
Motor vehicles & & \\
\hline
\end{tabular}

Source: Statistics South Africa, Report No. 30-02-02 (2005), Table 19, p. 145-150.

Although it is crude, this analysis does suggest that market power is more likely to arise on the selling side, and where buying power exists (possibly created through joint purchasing 
agreements), this is likely to be exercised against suppliers that have market power. This suggests that it is more likely to result in a situation of bilateral monopoly rather than the exercise of direct monopsony power. Where bargaining power exercised by buyers is countervailing, it may increase output in the upstream market. It may also increase the welfare of consumers in the downstream market, depending on the state of downstream competition. However, there may be instances where buying power concerns may be warranted. For instance, Cutts and Kirsten (2006) analyse price transmission along the value chain in four agro-food industries, namely the maize, bread, cooking oil and milk industries. The authors find that though there are many farmers at the first step of the value chain in all of these industries, the degree of concentration further downstream at the storage, milling or processing levels is significantly higher.

\subsection{Shape of the supply curve}

The supply curve of the sellers has been assumed to be upward sloping, which is necessary for the exercise of monopsony behaviour, since it enables the buyer to achieve a lower price by restricting the quantity demanded. If, for example, the input supply curve is horizontal, a reduction in the purchase of input has no effect on price. Consequently there is no monopsony effect. Similarly, if the supply curve is downward-sloping, a reduction in input purchased would result in higher prices, and this would not be an optimal strategy for the monopsonist. These possibilities are not merely of theoretical interest, and although an upward-sloping supply curve is standard in economic literature, the slope of the supply curve is a subject of debate, with the EU noting that for many goods this may not be the case (OECD, 2008:259). If an industry enjoys constant or increasing returns to scale, the supply curve is correspondingly flat or downward sloping, as increased production can take place at constant or declining costs. If, however, an expansion of the industry's output causes the prices of some key factor inputs to rise (which would happen if inputs were scarce, which may be the case with natural resources and labour), the supply curve would in general be upward-sloping. It is noted that in the case of a monopoly the corresponding requirement is for a downward-sloping demand curve, which is not a key consideration for competition authorities when assessing the ability of monopolies to raise price.

\subsection{Efficiencies}

It is widely recognised that efficiencies often arise from joint buying arrangements that have the potential to yield direct benefits to consumers. Through pooling purchasing volumes, a buyer group may be able to reduce its buying price, which often forms the rationale for forming a buyer group in the first place. If a buyer group is able to secure lower prices, the buyer will generally be able to buy more inputs and not less as found in the standard monopsony outcome. Moreover, it would seem that the realisation of efficiencies may often require setting the purchasing price jointly, as would be the case in securing volume discounts. In contrast, it is more difficult to imagine many circumstances which would require the parties of a joint selling arrangement to jointly set selling prices in order to harness the potential efficiencies associated with cooperative selling arrangements. 


\section{INTERNATIONAL APPROACHES TO JOINT PURCHASING}

It is instructive to examine how other jurisdictions tend to approach the analysis of buyer power and joint purchasing arrangements between firms. It is striking that in all major jurisdictions there is a significant degree of flexibility in the assessment of such activities, and certainly more flexibility is available than would seem to be afforded within South Africa on a strict reading of section $4(i)(b)$.

\subsection{Canada}

Paragraph 45(1)(a) of the Canadian Competition Act prohibits agreements between competitors "to fix, maintain, increase or control the price for the supply of the product". Importantly, this prohibition applies to the price for the supply of a product, and not to the price for the purchase of a product. As such, joint buying agreements, including those that are between firms that compete in respect of the purchase of products, are not prohibited by section 45 . They may, however, be subject to a remedy under the civil agreements provision in section 90.1 , where they are likely to substantially lessen or prevent competition (Competition Bureau Canada, 2009).

This explicit differential treatment for joint purchasing arrangements seems to flow from recognition in Canada that such collaborations are not necessarily of the same harmful character as joint selling arrangements. In this regard the Canadian Competition Bureau recognises that small- and medium-sized firms often enter into joint purchasing agreements to achieve discounts similar to those obtained by larger competitors and therefore quite tellingly conclude "[g]iven that such agreements can be pro-competitive, they are not deserving of condemnation without a detailed inquiry into their actual competitive effects; as such, they should only be subject to review under the civil agreements provision in section 90.1." (Competition Bureau Canada, 2009:11).

In determining whether a joint purchasing agreement substantially lessens or prevents competition the Bureau considers the impact in the relevant purchasing market - the upstream market. This depends on whether the agreement creates, preserves, or enhances monopsony or oligopsony power of the participants (Competition Bureau Canada. 2009). For concerns to arise, the parties must hold market power in the market for the purchase of the relevant input. Furthermore, the joint production agreement must be likely to reduce prices below the competitive level, resulting in a corresponding reduction in the input supplied or a corresponding decline in any other competition dimension. In considering whether an agreement substantially lessens or prevents competition the Bureau will generally not consider an agreement where the share of the relevant upstream market held by the parties to the agreement is less than $35 \%$. Moreover, the Bureau will generally not challenge an agreement on the basis of oligopsony power where the share of the four largest firms in the relevant upstream market is less than $65 \%$, or the share of the parties to the agreement is less than $10 \%$ of the relevant upstream market (Competition Bureau Canada, 2009).

If it is established that the parties hold monopsony power, the Bureau will examine a number of additional factors in determining whether the participants are likely to exercise this power, including elasticity of supply, upstream concentration, barriers to entry and the probability of exit in response to a reduction in prices. The Bureau will also consider the impact on the long-run source of supply and the possible costs to the parties of decreased output in the downstream market that may follow decreased input purchases (Canadian Bureau Competitor Collaboration 
Guidelines 2009).

\subsection{United States}

The treatment of joint buying arrangements, and competitor collaborations in general, in the US is more nuanced than in Canada. Competition Authorities in the US acknowledge that competitor collaborations are "often not only benign but pro-competitive" (Federal Trade Commission \& Department of Justice, 2000:1). As such, depending on the nature of the collaboration, two types of analysis are used by the Supreme Court to determine the lawfulness of an agreement among competitors: per se and rule of reason.

Per se prohibition for "naked" cartels. It has been deemed that certain types of agreements are likely to be so harmful to competition, and have no significant benefits, that they do not warrant time and expense required for an inquiry into their effects - and such agreements are deemed to be per se illegal (Federal Trade Commission \& Department of Justice, 2000:7). Such agreements are often referred to as naked cartels (Hovenkamp, 1999:2004). The types of agreements that have been held per se illegal include agreements among competitors to fix prices or output, rig bids, or share or divide markets by allocating customers, suppliers, territories, or lines of commerce (Federal Trade Commission \& Department of Justice, 2000). Generally such agreements are deemed to be illegal, without any further inquiry into other effects such as anti-competitive harms, pro-competitive benefits, or overall competitive effects.

Rule of reason prohibition for other collaborations. Horizontal competitor agreements not challenged as per se illegal are analysed under rule of reason to determine overall competitive effect. This category of collaborations generally offers some form of efficiency-enhancing integration of economic activity which the collaboration is deemed necessary to generate (Federal Trade Commission \& Department of Justice, 2000). US Antitrust Guidelines indicate that this rule of reason analysis focuses on the relative state of competition with and without the agreement in question (Federal Trade Commission \& Department of Justice, 2000). In this approach the central analysis "is whether the relevant agreement likely harms competition by increasing the ability or incentive profitably to raise price above or reduce output, quality, service, or innovation below what likely would prevail in the absence of the relevant agreement" (Federal Trade Commission \& Department of Justice, 2000:10). As such this entails a flexible inquiry and varies in focus and detail depending on the nature of the agreement and market circumstances.

The key question for this paper is in what category joint-purchasing agreements are assessed: those considered as per se illegal (i.e. naked cartels), or those recognised to have procompetitive elements and considered under a rule of reason approach? Unlike Canada, the US does not explicitly distinguish between the treatment of joint purchasing and joint selling activities in their determination of what types of agreements fall under the above two categories. This requires a characterisation of a particular agreement in question in order to determine whether it should be considered as per se illegal or instead considered under a rule of reason approach.

A joint buying arrangement designed to lower prices and restrict output could be considered as per se illegal in the US. This principle has been established in a number of US cases such as United States vs Socony-Vacuum Oil (1940) and Vogel vs American Society of Appraisers (1984). However, it is well recognised by US commentators that since joint buying arrangements by 
relatively small traders is generally "both efficient and desirable" particular care should be taken when characterising such collaborations and that in general these agreements should be analysed under a rule of reason approach (Hovenkamp, 1999:2012). In practice it would seem that US courts have tended to follow this approach and have not always treated buying cartels with the same hostility as selling cartels. In particular, joint buying by competitors has often been examined under a rule of reason approach, even where it involved the joint setting of a purchase price. This is clearly seen in All Care Nursing Services v. High Tech Staffing Services (1999), where rule of reason analysis was applied to a hospital joint venture for the joint purchase of nursing services. Other key instances in the US where a rule of reason approach has been applied to joint purchasing agreements which ultimately lead to their sanction include Sewell Plastics v. Coca-Cola (1991), Northwest Wholesale Stationers v. Pacific Stationery \& Printing co (1985) and United States v. Topco Association (1972).

\subsection{Europe}

The $\varepsilon U$ Commission also allows for a rule of reason approach for joint purchasing agreements, and only considers such agreements as per se illegal when the object of the agreement is anticompetitive. More specifically, Article 101(1) prohibits agreements between undertakings "which have as their object or effect the prevention, restriction or distortion of competition". This includes the direct or indirect fixing of purchase or selling prices (Article $101(1)(a)$ ). In assessing the provisions of Article 101(1) it is first necessary to consider the 'object' of the agreement, where the object in this context means the "objective meaning and purpose of the agreement considered in the economic context in which it is to be applied" (Whish, 2009:116). In instances where an agreement has as its object the restriction of competition, it is unnecessary to demonstrate anti-competitive effects in order to fall under Article 101(1). That is to say, it is effectively a per se prohibition. A consideration of the effect is only necessary if it is unclear that the object of the agreement is to harm competition (Whish, 2009).

The European Commission has issued guidelines on the applicability of Article 101 (European Commission, 2011), which includes guidelines on the assessment of joint purchasing agreements. It finds that joint purchasing arrangements restrict competition by object "if they do not truly concern joint purchasing, but serve as a tool to engage in a disguised cartel, that is to say, otherwise prohibited price fixing, output limitation or market allocation" (European Commission, 2011:par. 205). It states further that agreements which involve the fixing of purchase prices can have the object of restricting competition; however, "this does not apply where the parties to a joint purchasing agreement agree on the purchasing prices the joint purchasing arrangement may pay to its suppliers for the products subject to the supply contract" (European Commission, 2011:par. 206). In the latter case, an assessment is required to determine whether the agreement is likely to restrict competition.

In instances where joint purchasing arrangements do not have as their object the restriction of competition, the arrangements must be analysed "in their legal and economic context with regard to their actual and likely effects on competition" (European Commission, 2011:par. 207). In applying a rule of reason analysis to purchasing agreements, the guidelines indicate that if the combined market shares of the parties to the joint purchasing agreement are below $15 \%$ on the purchasing and selling markets, the purchasing agreement is unlikely to fall foul of Article 101. Furthermore, if the parties are not active in the same selling market, the joint purchasing agreement is unlikely to give rise to restrictive effects. This does not imply that at levels above the $15 \%$ threshold agreements are automatically assumed to have an anti-competitive effect; 
rather, a more detailed assessment of the impact of the agreement is required, which involves a consideration of a number of factors, including, market concentration and countervailing power (European Commission, 2011).

The European Commission also allows for a consideration of efficiency gains which may outweigh the anti-competitive effects, with the guidelines recognising that joint purchasing can lead to significant efficiency gains, including cost savings from lower purchase prices or reduced transaction, transportation and storage costs. For the weighing up of efficiency benefits against the restrictive effects of the agreements to hold, the efficiency benefits must be passed on to consumers (European Commission, 2011).

\section{IMPLICATIONS FOR THE TREATMENT OF JOINT PURCHASING}

Joint purchasing arrangements often require the setting of a common purchase price, which may technically be captured under the per se prohibition of section 4(1)(b). However, these agreements also often carry with them real efficiency benefits, and, as such, can often be procompetitive in their nature. This is particularly true in the South African context, where upstream concentration is common across industries, which would suggest that many joint buying arrangements would be operating in an environment of a bilateral monopoly.

Given the mechanisms of possible competitive harm, these agreements would not seem to necessarily convey the same extent of likely harm that would normally be associated with a joint selling agreement which involves the fixing of a selling price. This point has been recognised by Hovenkamp, who has insightfully pointed out that: "Indeed, the gains to be had from joint buying are both more frequently enjoyed and more visible than the comparable gains that can be obtained from joint selling" (Hovenkamp, 1999:par. 2010).

As such there may well be scope for a somewhat differential treatment between joint purchasing and joint selling behaviour - if not in law then practically in terms of prosecution priority.

From an economic point of view there would appear to be scope to take a less draconian approach to the joint purchasing agreements and to assess many of them on a rule-of-reason basis. This is not to say that joint purchasing agreements will never be anti-competitive or that joint buying cannot impose a harmful monopsony effect on the market. However, assuming competitive harm on a per se basis is not a reliable heuristic, as in many cases this anticompetitive intention or effect will simply not be present. It may also be that the considerations noted in this paper may be relevant in terms of a more accurate characterisation of specific joint purchase agreements - to the extent that such characterisation of behaviour is indeed relevant as to whether behaviour should, or should not, fall under section 4(1)(b).

This would seem to be broadly consistent with the approach in foreign jurisdictions, which appear to have sufficient flexibility in their characterisation of joint purchasing agreements so as to consider only the more hard-core buying cartels (whose intention and effect is to depress output and the purchase price below the competitive level) as per se illegal. Joint purchasing agreements are however more generally considered in these jurisdictions under a rule-of-reason approach. 


\section{CONCLUSION}

There are good reasons to suggest that joint purchasing agreements should not be afforded the same treatment as selling agreements - joint purchasing agreements are often efficiencyenhancing, which is pro-competitive, and do not necessarily convey the same extent of harm associated with joint selling arrangements. Despite this, joint purchasing agreements, which often require the setting of a purchase price, may be captured under the per se prohibition of section $4(1)(b)$, which does not allow for a consideration of efficiency and pro-competitive effects that often underpin the creation of joint purchasing agreements. The current ambiguity regarding the treatment of joint buying agreements under section $4(1)(b)$ could have negative implications for South African business. The risk is that South African firms - often small-tomedium-sized businesses - decline from engaging in efficiency-enhancing and pro-competitive joint buying arrangements due to the potential risk of technically falling foul of the per se prohibition contained in section 4(1)(b) of the Act.

\section{LIST OF REFERENCES}

ABA Section of Antitrust Law. (2008). Issues in Competition Law and Policy, volume l. Chicago: ABA Book Publishing.

Alexander, L. (2007). Monopsony and the Consumer Harm Standard. Georgetown Law Journal, 95(5), pp. 1611-1643.

Areeda, P.E. \& Hovenkamp, H. (2003). Antitrust Law: An Analysis of Antitrust Principles and Their Application, volume XII, 2003 edition. New York: Aspen Law \& Business.

Carlton, D.W. \& Perloff, J.F. (2005). Modern Industrial Organization, $4^{\text {th }}$ edition. Boston: AddisonWesley.

Chen, Z. (2007). Buyer Power: Economic Theory and Antitrust Policy. Research in Law and Economics, 22, pp. 17-40.

Competition Bureau, Canada. (2009). The Competitor Collaboration Guidelines. [On-line] Available: http://www.competitionbureau.gc.ca/eic/site/cb-bc.nsf/eng/03177.html. (Accessed 18 March 2011)

Cutts, M. \& Kirsten, J. (2006). Asymmetric Price transmission and market concentration: An investigation into four South African agro-food industries. South African Journal of Economics, 74(2), pp. 323-333.

European Commission. (2011). Guidelines on the applicability of Article 101 of the Treaty on the functioning of the European Union to horizontal cooperation agreements, Official Journal of the European Union, $\mathrm{Cll} / \mathrm{l}$.

Fedderke, J. \& Szalontai, G. (2005). Industry Concentration in South African Manufacturing: Trends and Consequences, 1972-1996. (World Bank Africa Region Working Paper Series No. 96.) [On-line] Available: http://www.worldbank.org/afr/wps/wp96.pdf. (Accessed 18 August 2010).

Federal Trade Commission and the U.S. Department of Justice. (2000). Antitrust Guidelines for Collaborations among Competitors. [0n-line] Available:

http://ftc.gov/os/2000/04/ftcdojguidelines.pdf. (Accessed 18 March 2011). 
Griffiths, A. \& Wall, S. (2000). Intermediate Microeconomics: Theory and Applications, $2^{\text {nd }}$ edition. Essex: Pearson Education.

Hovenkamp, H. (1999). Antitrust Law, volume XII. New York: Aspen Law \& Business.

Hovenkamp, H. (2005). Federal Antitrust Policy: The Law of Competition and its Practice, $3^{\text {td }}$ edition. West Virginia: Thomson West.

Jacobson, J.M. \& Dorman, G.J. (1991). Joint Purchasing, Monopsony and Antitrust. The Antitrust Bulletin, volume XXXVI, number 1. New York: Federal Legal Publications.

Malikane, C. \& Roberts, S. (2001). Production and technology changes, restructuring and employment in the plastics sector. (TIPS Working paper 2-2001.) [On-line] Available:

http://www.tips.org.za/files/417.pdf. (Accessed 18 August 2010).

Noll, R.G. (2005). Buyer Power and Economic Policy. (SIEPR Discussion Paper No. 04-08.) [On-line] Available: http://www-siepr.stanford.edu/papers/pdf/04-08.pdf. (Accessed 18 August 2010).

0ECD. (2008). Policy Roundtables on Monopsony and Buyer Power: 2008. [0n-line] Available: http://www.oecd.org/dataoecd/38/63/44445750.pdf. (Accessed 18 August 2010).

Office of Fair Trading (OFT). (1998). The Welfare Consequences of the Exercise of Buyer Power. OFT Research Paper 16. Report prepared by Dobson, Waterson and Chu for OFT.

Office of Fair Trading (OFT). (2004). Assessment of Market Power. Competition Act Guideline 0FT415a, London.

Office of Fair Trading (OFT). (2007). The competitive effects of buyer groups. (Economic Discussion Paper.) Report prepared by RBB Economics for OFT.

Roberts, S. (2004). The Role of Competition Policy in Economic Development: The South African Experience. (TIPS Working Paper 8-2004.) [On-line] Available: http://idrc.ca/uploads/userS/11798701451The_Role_of_Competition_Policy_in_Economic_Development.pdf. (Accessed 18 August 2010).

Roberts, S. \& Zalk, N. (2004). Addressing market power in a small, isolated, resource-based economy: the case of steel in South Africa. CRC Third International Conference, Cape Town: South Africa. 7-9 September 2004.

Salop, S.C. (2005). Anticompetitive Overbuying by Power Buyers. The Antitrust Law Journal, 72(2), pp. 669-715.

Sewell Plastics v Coca-Cola, 498 U.S. 1110 (1991).

Statistics South Africa. (2005). Manufacturing Industry: 2005. (Report No. 03-02-02.) Pretoria.

United States Court of Appeals, Eleventh Circuit (1998). All Care Nursing Services v. High Tech Staffing Services, 135 F.3rd 740.

United States Court of Appeals, Seventh Circuit (1984). Vogel v. American Society of Appraisers, 744 F.2d 598 .

United States Supreme Court (1940). United States v. Socony-Vacuum Oil Co, 310 U.S. 150.

United States Supreme Court (1972). United States v. Topco Association, 405 U.S. 596.

United States Supreme Court (1985). Northwest Wholesale Stationers v. Pacific Stationery \& Printing Co, 472, U.S. 284. 
Varian, H.R. (1996). Intermediate Microeconomics: A Modern Approach, 4th edition. New York: W.W. Norton and Company.

Whish, R. (2009). Competition Law, $6^{\text {th }}$ edition. Oxford: University Press. 


\section{APPENDIX 1:}

\section{Mathematical Representation of the Basic Monopsony Model}

The monopsonist, being a profit maximising firm, chooses the quantity of input $\boldsymbol{x}$ that maximises:

$$
p f(x)-w(x) x
$$

Where

$x \quad$ The commodity produced by the sellers

$p \quad$ The price charged by the monopsonist in its downstream market (which is beyond its control and hence taken to be constant by the monopsonist)

$f(x) \quad$ The production function of the monopsonist. In other words, $f(x)$ is the quantity of final good produced when using $x$ units of input. The first derivative of $f(x)$ is assumed to be positive and the second derivative is assumed to be negative. This assumption is a statement of the law of diminishing returns to a factor of production, and says that as the inputs used increase so does output, but does so at a diminishing rate. Diminishing returns is a standard assumption in the economics literature.

$w(x) \quad$ The supply curve of the sellers $w(x)$ is the price that must be paid to the sellers when buying $x$ units of input. An upward-sloping supply curve implies that the first derivative of $w(x)$ is positive.

The condition for profit maximisation is that the marginal revenue from hiring an extra unit of the input should equal the marginal cost of that unit. Mathematically, the condition is obtained by differentiating the expression with respect to output $(x)$ for the monopsonist's profit and setting it equal to zero. This yields:

$$
p \frac{d f(x)}{d x}=w(x)+x \frac{d w(x)}{d x}
$$

Since a competitive downstream market has been assumed (and thus $p$ is a constant), the lefthand side is simply the marginal revenue from hiring an extra unit of input. The left-hand side is alternatively called the Value of Marginal Product (or VMP) curve (Griffiths \& Wall, 2000:394, 402; 0ECD, 2008:29). This curve is also the derived demand for the upstream input since it gives the profit maximising choice of input by the monopsonist corresponding to each level of input price (Griffiths \& Wall, 2000:404).

The right-hand side is the marginal cost to the buyer (alternatively called the Marginal Factor Cost (MFC)) of increasing its input purchase by a small amount. Since the buyer has monopsony power, if it were to increase its purchase slightly, it would not only have to pay the cost of those extra units (given by $w(x)$ ) but also incur an increased cost on all the units purchased as a result of increasing the price of the inputs (given by $x \frac{d w(x)}{d x}$ ). This consideration, undertaken by the monopsonist, would not occur if it lacked buying power. In that case the buyer would be unable to influence the price at which the sellers sold their inputs and thus the term $x \frac{d w(x)}{d x}$ would be zero. Its marginal cost would then simply be $w(x)$. Thus the marginal cost to the monopsonist (or MFC) must always be greater than a situation in which it lacked buying power. 
Anderson, Fiandeiro \& Choudhary 